\title{
Ethnologies
}

\section{Of Chiefs and Kings}

\section{Wendat and British diplomatic traditions, 1838 to 1842}

\section{Annette de Stecher}

Volume 37, numéro 2, 2015

URI : https://id.erudit.org/iderudit/1041490ar

DOI : https://doi.org/10.7202/1041490ar

Aller au sommaire du numéro

Éditeur(s)

Association Canadienne d'Ethnologie et de Folklore

ISSN

1481-5974 (imprimé)

1708-0401 (numérique)

Découvrir la revue

\section{Citer cet article}

de Stecher, A. (2015). Of Chiefs and Kings: Wendat and British diplomatic traditions, 1838 to 1842 . Ethnologies, 37(2), 103-130.

https://doi.org/10.7202/1041490ar
Résumé de l'article

Cet article porte sur le rôle des relations diplomatiques Wendat, analysées par le biais de documents écrits et iconographiques et de l'art des tenues de cérémonie. Il décrit les interactions diplomatiques entre les communautés Wendat et britanniques entre 1838 et 1842, lors desquelles les Wendat ont affirmé leurs engagements pour un soutien civil et militaire et ont assuré une présence continue dans leurs territoires ancestraux. Par une représentation dynamique de leur identité publique indigène, ils sont allés en contradiction avec l'image romantisée et profondément enracinée dans l'imagination populaire d'une race en disparition. Ces événements ont marqué un moment particulier dans l'histoire des Wendat et de leurs engagements diplomatiques et échanges interculturels avec les dirigeants européens, qui remontent au début du XVII ${ }^{\mathrm{e}}$ siècle.

Les témoignages d'époque des Wendat et des Britanniques apportent des regards de la part de membres individuels de chaque communauté, tandis que les souvenirs des anciens Wendat sur les traditions cérémoniales entretiennent un savoir collectif sur l'importance de ces événements pour les Wendat, à un moment important de l'histoire de Wendake et du Bas-Canada.
Ce document est protégé par la loi sur le droit d'auteur. L'utilisation des services d’Érudit (y compris la reproduction) est assujettie à sa politique d'utilisation que vous pouvez consulter en ligne.

https://apropos.erudit.org/fr/usagers/politique-dutilisation/ 


\section{Of Chiefs And KIngs}

Wendat and British diplomatic traditions, 1838 to 1842

\section{Annette de Stecher \\ University of Colorado Boulder}

On a winter's day in February 1838, at the Wendat village of Lorette in what was then Lower Canada, Grand Chief Nicolas Vincent Tsawenhohi welcomed Judge Robert Symes into the community as an honorary chief. ${ }^{1}$ Before an audience of over 200 people, bringing together Anglophone and Wendat communities, Judge Symes, "attired in full costume and looking very like an Indian certainly," was adopted as Chief Hotsawati- one who acts as mediator, peacekeeper. Earlier that day, Lieutenant Vivian of the Coldstream Guards, a British regiment stationed at the Quebec garrison, was also adopted as chief, "a pris un nom," took a name: Sharenses-an overspreading tree (The Literary Transcript and General Intelligencer, 1838). Between 1838 and 1842, the period when the Guards were stationed in Quebec, at least three young officers were presented with a nom de guerre by the Wendat chiefs (Tahourenché, Journal, 29 January 1840; 25 February 1840). On January 14, 1842, four years later, Lieutenant General Sir James McDonnell, head of the Brigade of Guards, held a formal reception at Chateau St. Louis, the official residence of the Crown's representative in the Canadas, to receive Grand Chief Nicolas Vincent and his war chiefs. Chief Hotsawati presented the Grand Chief and War Chiefs to Sir James and the assembled guests.

This article is about the role of Wendat diplomatic traditions, explored through documentary and pictorial evidence and the arts of ceremonial dress. I will describe diplomatic interactions between Wendat and British communities between 1838 and 1842, through which the Wendat affirmed commitments of military and civilian support and asserted a continued Wendat presence in their traditional territories. By their dynamic public representation of Indigenous identity in Quebec City, they denied the then

1. I would like to thank the reviewers of this article for their invaluable feedback and assistance. 
widely held romanticized notion of the vanishing race, deeply rooted in the popular imagination.

These events, which took place over a four-year period, marked a particular moment within a Wendat history of diplomatic engagement and intercultural exchange with European leaders, extending back to the seventeenth century (Vincent 1984: 321-323). A fascinating narrative emerges, through the frequency of diplomatic occasions and the unusual richness of firsthand sources that give us a number of individual and journalistic accounts. Wendat and British participants and observers furnish multiple perspectives. Grand Chief François-Xavier Picard Tahourenché and Wendat leader Paul Picard Honda8onhont kept detailed records, writers for the Quebec Anglophone press described eyewitness accounts, and James Alexander du Pres, third Earl of Caledon and Captain in the Coldstream Guards, wrote extensive letters to his mother and grandmother, offering firsthand commentary of his visits to Wendake (Lorette) and meetings with Wendat chiefs. Wendat elders' recollections of ceremonial traditions and events of the time, recorded by anthropologist Marius Barbeau in 1911, give important community knowledge and insight into the significance of these events to the Wendat. These accounts bring us perspectives of individual members of each community at an important point in the history of Wendake and Lower Canada.

Ceremonial clothing, exquisitely embroidered in moose hair by Wendat women artists, was a central and constitutive element of these diplomatic events. Worn by Wendat chiefs and presented as gifts to those adopted into the community as honorary chiefs, these coats, moccasins, leggings, and headdresses were a highly visible and widely admired public statement of Wendat identity and culture and its continuity through time. Similar examples of clothing, bought by British visitors, appear to emulate this chiefly style. We can see this special occasion dress at its best in Henry Daniel Thielcke's tableau portrait commissioned by Judge Symes, recording the moment when he became Chief Hotsawati: Presentation at Lorette of the newly elected chief at the Huron Tribal Council, 1840 (Figure 1). The portrait of Three Chiefs of the Huron, by Edward Chatfield, taken at the time of their presentation to King George IV, is another detailed image of chiefly apparel in this period (Figure 2). The chief's ensemble presented to Swedish Consul General Folke Cronholm in 1905 on the occasion of his adoption as an honorary chief, shows the clothing and gift tradition unchanged (Figure 3). The role of clothing in the investiture of a chief, to European viewers and to the recipient, in its materiality and the power that 


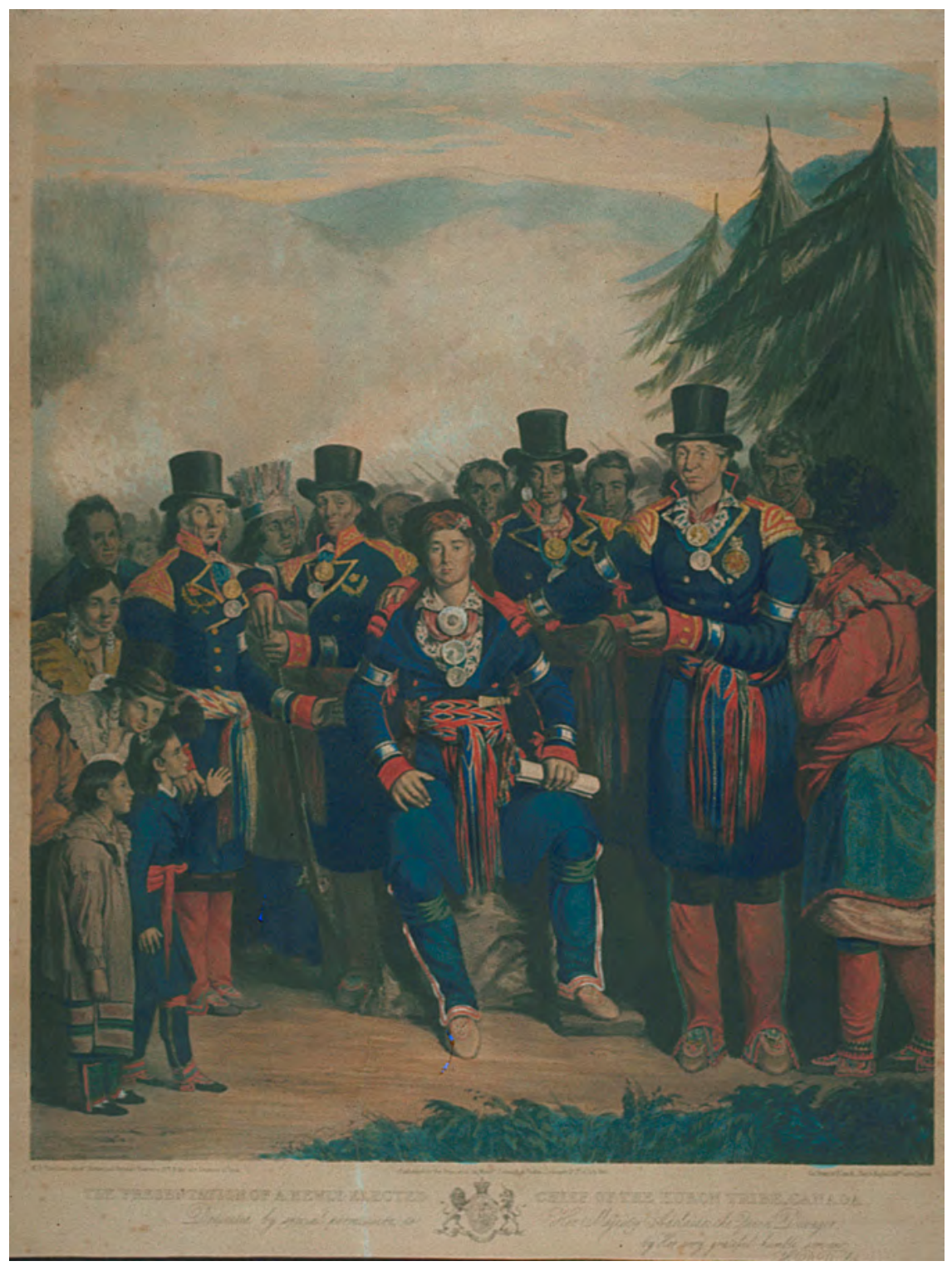

Figure 1. Henry Daniel Thielcke, Presentation at Lorette of the newly elected chief at the Huron Tribal Council, 1840. McCord Museum M20009 


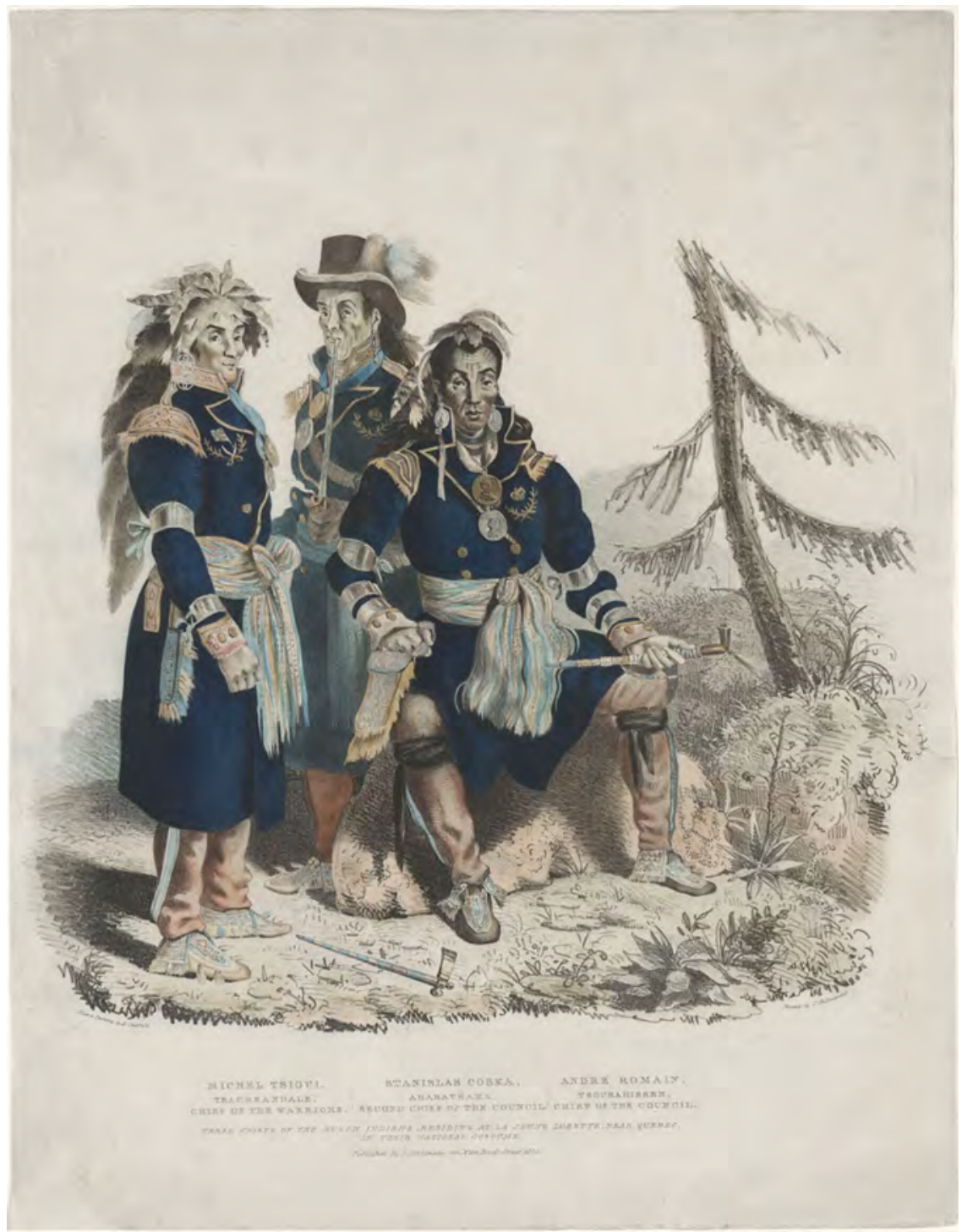

Figure 2. Edward Chatfield, Three Chiefs of the Huron, 1825. Michel Tsiouï Teacheandale, Stanislas Coska Aharathaha, Andre Romain Tsohahissan. Library and Archives Canada, Acc. No. R9266-3186. 


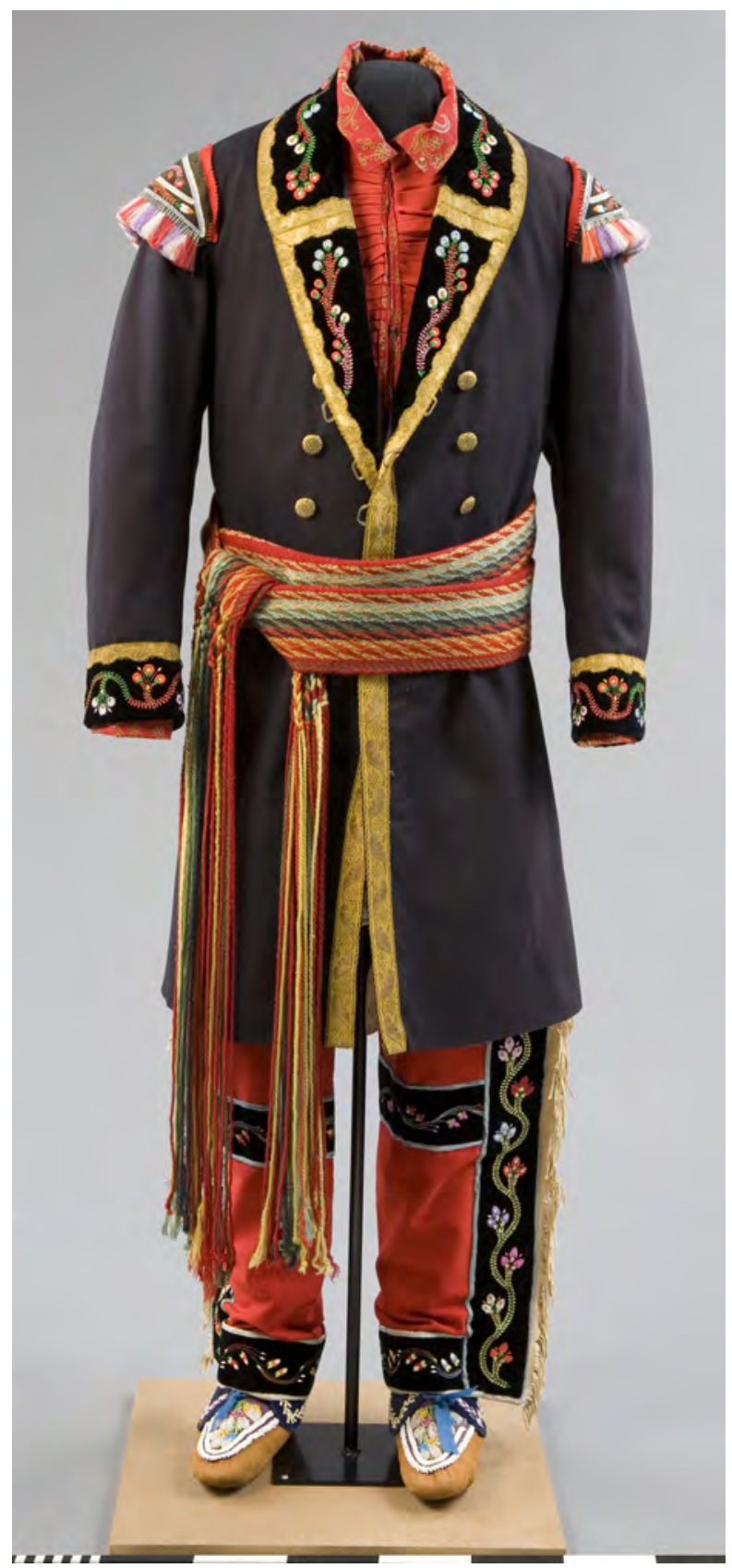

Figure 3. Caroline Gros-Louis, Chief's ceremonial dress, 1905, coat, 1. 112 cm, w. 40-49 cm. Folke Cronholm Collection. Etnografiska Museet, Stockholm 1936.22.0015 


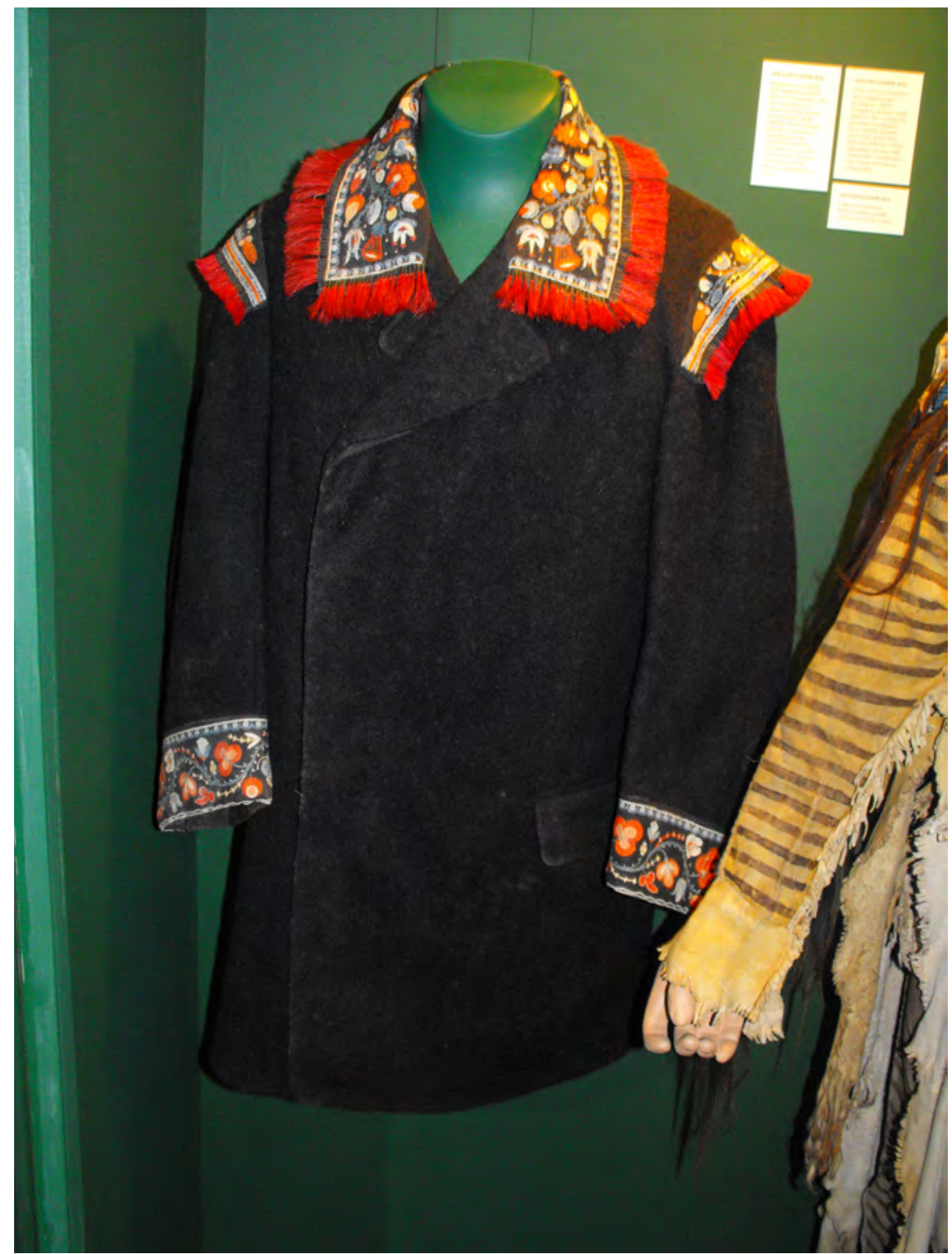

Figure 4. Coat, moosehair, wool. Sebastian Alexander Leith-Hay, Leith Hall. National Trust for Scotland. 
it appears to have conveyed, is made evident in contemporary responses to these ceremonies. The moose hair-embroidered wool coat acquired by Lieutenant Colonel Sebastian Leith-Hay of the 93rd Sutherland Highland Regiment, who was a young Ensign when he was stationed in Lower Canada during this period, and the coat from the Tollemache family collection, probably acquired by Lord Wilbraham Spencer Tollemache, also in Quebec with the Coldstream Guards between 1838 and 1842, are examples of the embroidered clothing similar to chiefly dress that were collected by military visitors in this period (Figure 4).

I will open with a brief history of the Wendat nation, then an outline of the political situation in the Canadas at this time, followed by a detailed account of the adoption of Judge Robert Symes, the presentation of noms de guerre, and the reception held by Sir James MacDonnell to honour the new Prince. I will describe these diplomatic meeting points in terms of their significance to the Wendat, to the British military, and to the larger settler community. The moose hair-embroidered chief's apparel that was integral to these events helps visualize and give material support to the firsthand accounts.

\section{The Wendat of Wendake, Quebec}

The Wendat (Huron) of Lorette, today known by its Wendat name of Wendake, are the descendants of the Christian Huron who settled outside Quebec City in 1649 after the dispersal of the Huron confederacy from their Georgian Bay homelands. Their ancestral traditions, diplomatic protocols based in Great Lakes Indigenous practices, developed in an area that was a centre for regional trade routes and helped build far-reaching networks and alliances.

In the eighteenth century the Wendat were French allies and active in the fur trade. With entrepreneurial vision, they developed a commercial enterprise supplying military equipment to the Quebec garrison, an indication of the community's ability to adapt to changing circumstances and identify new trade opportunities. The French soldiers who came to the Great Lakes region were ill-equipped for the cold winters of the Northeast and the Wendake community supplied moccasins, snowshoes, canoes, paddles and other goods (Balvay 2006: 216, 221, 229). ${ }^{2}$ After the British takeover of Quebec, through the Huron-British Treaty (Traité

2. LAC (Library and Archives Canada), MG1-C11A, (archives des colonies, correspondence générale, Canada), vol. 117, «Dépenses générales,» 1747, folio 95-116, reel F-118. 
Huron-Britannique) negotiated by Wendat chiefs in 1760 , the community established trade ties with the newly arrived military forces (Vincent 1984: 145-146). In Indigenous traditions, trade and military alliance went hand in hand, and the Wendat were British allies in the 1776 conflict with American revolutionary forces and again in the War of 1812 (Sawaya 2000b : 2116-2117).

As demand for furs diminished in the early nineteenth century, the production of moose hair-embroidered souvenir arts, already well established in the eighteenth century, became central to the Wendat economy, as growing numbers of visitors came to the Quebec region. The influx of British military and administrative personnel and their wives and families in the late 1830 s made this market even stronger. With the growing military population, Wendat contracts with the British government became increasingly substantial. In 1837, the community filled a contract with the government for over 1,300 pairs of snowshoe moccasins and over 700 pairs of snowshoes. ${ }^{3}$ Although the increased populations brought the benefit of expanded markets, they also brought increased demands for land, as waves of settlers, the lumber industry, and private hunting clubs encroached on Indigenous hunting territories (Sawaya 2000a: 2175).

In this period, the traditional form of Wendat government was in place. Chiefs were appointed for life. When a war chief was chosen, there was a feast and celebration; he was presented with a name, with leaders from the Federation of the Sept Feux, the seven Indigenous nations of the Saint Lawrence Valley, or from the British government, in attendance to recognize the new leader. On the investiture of a new Grand Chief, a ceremony on an even larger scale was held (Vincent 1984: 82). It was in this context, of an Indigenous framework of customs, songs, dances, and speeches, passed down through generations, that Wendat leadership met with British colonial leaders and addressed representatives of the Crown nation to nation.

From a Wendat perspective, diplomatic events furthered economic and political goals; through them Wendat chiefs created paths of access to the highest and most powerful figures in the British empire, from governorgenerals, to princes, to the King. This was critical to negotiate changing times, the pursuit of land claims, maintain and develop commercial interests, and assert Wendat rights to national hunting territories, the Nionwentsïo. Events that built recognition and opened lines of communication were an opportunity to represent Wendat national identity and presence, while

3. Contrat du Gouvernment, Tahourenché, Journal, n.p. 
making space for negotiation. The Wendat community were a small minority in this period, their population around 200. ${ }^{4}$ As a member of the Indigenous Federation of the Sept Feux, however, they were part of a larger Indigenous political presence. This, together with the strong public profile achieved through their diplomatic initiatives, brought them greater political recognition in the region than their numbers would suggest.

At the center of Wendat celebrations, both within the community and with foreign guests, was the sagamite feast, and as we will see in the description of adoptions, presentation of noms de guerre, and the honouring of the birth of the Prince, the tradition of the sagamite, the songs, dances, and special occasion dress, drew members of British and Euro Canadian communities to the Wendat village, where they were welcomed and honoured by the feast and Wendat hospitality itself.

The sagamité feast was held on many occasions, from the election of a war chief, a grand chief, presenting a name to a young person of the community or to someone outside the community, and sometimes, these feasts were held just for the community, for everyone to enjoy themselves. At the heart of the celebration was a large cauldron of soup or stew, made by women appointed by the Chiefs. It was made of Indian corn, beans, and different kinds of meat. The cauldron was prepared either outside or in the largest house in the community. When it was ready, all the community came, in their special occasion dress. After everyone had eaten, the best dancers were invited to dance and sing, performing around the cauldron. Traditional dances such as the war dance, the snake dance, and others were accompanied by the Tchitchikwe (rattle) or drum. ${ }^{5}$ This event was an important element of community cohesiveness, as well as part of Wendat hospitality, bringing guests to the community to share food and celebration, and we will see its importance in the ceremonies that took place between 1838 and 1842.

\section{Politics in Lower Canada, 1838 to 1842}

This was a time of conflict, with the Patriot Rebellions of 1837 and 1838, the threat of invasion by American citizens in support of the Patriots, and tensions with the American government about the vaguely-defined border between the state of Maine and British territory to the north of it. This border was not determined until 1842 (Foster 1896: 114). The conflict

4. Enclosure 3 in No. 11, Return (Great Britain, Colonial Office, 1839: 36).

5. Marius Barbeau fonds, Antoine Bastien Box 51 B.G. 13.1 (1-3); Gaspard Picard père Box 51 B.G. 13.4 (1-4); Antoine Bastien Box 67, B.G. 206.13 (7). 
with the Patriots began in 1837, as French Canadian reformers rebelled against the British government. American sympathizers, not supported by the American government, it seems, came across the border in the Niagara region. The Patriots sought "democratic reform and responsible government"; the recognition of French Canadian interests and their actions played an important role in the move to parliamentary democracy and the Canadian Confederation (Hall 2012: 66). Regiments of the Coldstream and Grenadier Guards arrived in Quebec in 1838 to reinforce the existing British military presence in Quebec. There were a number of direct engagements, but British forces defeated the insurgents and the conflict ended in December 1838.

The Guards remained in Quebec until 1842 to strengthen the British position in the Canadas in light of ongoing concerns over the border between Maine and New Brunswick, settled by the Webster-Ashburton Treaty of 1842 (Jones 2009: 145). Although no actual fighting broke out, there were tense moments. Had this situation escalated, British troops in Quebec would have travelled to the Maritime region. Wendat warriors had proven their loyalty and ability during the War of 1812 in a similar movement of forces. In 1814, Nicolas Vincent Tsawenhohi, Andre Romain, and a number of other Wendat men guided British troops through winter terrain, successfully leading the "convois militaires" (military convoys) from Fredericton to Kingston (Sawaya 2015: 100). In the immediacy of armed combat in the Canadas, in this period the Wendat and other members of the Sept Feux Indigenous federation were recognized in their valued position as allies (Great Britain, Parliament, House of Commons, 1839: 246, 274-275, 315, 342-343).

\section{Adoption of Judge Robert Symes, Chief Hotsawtati}

To strengthen relations with non-Indigenous military, government, and civilian leaders the Wendat drew on established Great Lakes diplomatic traditions. ${ }^{6}$ The practice of adoption brought members of allied nations into

6. Samuel de Champlain was one of the first Europeans to negotiate trade and military alliances with Wendat chiefs, and from his description of events, he received an offer of adoption into the Wendat nation. However, it is unlikely that he understood the invitation and the honour it signified. In 1609 he fought beside the Wendat against the Iroquois, proving that he was an ally worthy of merit in times of war, and he had demonstrated that the French were valuable trade partners. Champlain reported that Wendat leaders invited him to travel back with them to their country, to live there and help them as brothers. Champlain did not take them up on their offer, but on his return to France he gave a gift to King 
the Wendat community in kinship terms, integrating European newcomers into an Indigenous political framework (Trigger 1998: 64). In his discussion of early contact Wendat trade and diplomatic practices, Bruce Trigger writes that commerce was understood as a reciprocal exchange of gifts within a kinship network and the Wendat's Indigenous trade partners were referred to in kinship terms, family connections that were probably formalized through ties of adoption (Trigger 1998: 64). Judge Syme's adoption as honorary chief followed this tradition.

Antoine Bastien, son of Grand Chief Maurice Sébastien Agniolen, described the election of Judge Symes as honorary chief: "Lorsqu'ils ont élu M. Sims chef honoraire ils ont fait la sagamité et la danse. Tahourenche [Chief François-Xavier Picard Tahourenché] a dit qu'il avait présenté à Sims la plus belle paire de raquettes et de souliers qu'il était possible de faire a cette époque-là. Sims était beaucoup aimé de la tribu et il venait souvent à Lorette" [When they elected Monsieur Sims as honorary chief they made held a sagamité feast and a dance. Tahourenche said that he presented Sims with the most beautiful pair of snowshoes and moccasins that it was possible to make at that time. Sims was much liked by the tribe and he came often to Lorette] (Lainey 2004: 45). ${ }^{7}$

A writer for the Quebec press described this same event, which was part of a three-day celebration in Lorette that began with the marriage of a young couple, followed by the adoption ceremonies of two chiefs, first Lieutenant Vivian and then Judge Robert Symes (The Literary Transcript and General Intelligencer, 1838). The reporter describes the "installation of Lieut. Vivian, A.D.C. and Robert Symes, Esquire, as Chiefs of the Huron tribe." He describes the atmosphere of celebration in Lorette, these

Henry IV, a belt beautifully woven with porcupine quill (Champlain, 1929, vol. 2: 99-101, 104-105, 109-110). His description of Wendat and Algonquin women's virtuosity in quillwork suggests that it was produced in one of these closely allied communities: a precious gift to mark an important event and establish relations with military and commercial allies (Champlain, 1929, vol. 3: 132-133). This, together with the Wendat chiefs' invitation, strongly suggests that he was invited to become a member of the Wendat community and that he was regarded by the Wendat as part of their kinship network, as an adopted member of the community. (Champlain, 1929, vol. 2: 69, 102, 106). Trader-soldier John Long's description of his adoption by the Wasses in 1777 demonstrates the continuity of this tradition in the Great Lakes region in the eighteenth century (Long 1971: 45-46).

7. Marius Barbeau fonds, Fêtes Lorette, Box 51, B.G. 13.1. Antoine Bastien said that he learned about events in the early nineteenth century from Grand Chief Simon Romain, Touhanrenche, his own father Maurice Bastien Agniolen, and Philippe Vincent Teonatasta. 
"important events" having attracted "a large amount of the "beauty and fashion' of Quebec who entered into the spirit of the different amusements that prevailed, with much glee." He describes the dancing and music that was a theme of the celebrations, "distinctions of rank set aside," while "the principle residences of chiefs and others becoming an 'open house," the "fiddlers, fifes, and tambourines" that set everyone dancing, and the "picturesque nature of the scene" heightened by the large number of different uniforms together with "the dress of the Indians."

The festivities paused for the more solemn ceremony of adoption, which took place in the home of Chief Andre Romain Tsohahissan. The community gathered around the sagamité cauldron and the chiefs led their "brother" into this circle, the Judge "attired in full costume and looking very like an Indian certainly." Grand Chief Nicolas Vincent Tsawenhohi made a speech and presented Judge Symes with his Huron name, Hotsawati, he who has defended his country and acts as mediator. Hotsawati's "commission" was read out, in Huron, French, and English, specifying the assistance the Judge had rendered the community during the cholera epidemic in 1834 . Symes made a speech to thank the Wendat community, and expressed his appreciation of the honour he had received, saying "My friends, I receive this mark of distinction... with the greatest pleasure, and if at any future time I can assist you, the opportunity shall not be lost... I trust I shall not disgrace the distinguished name which you have now given me." The ceremony concluded, the sagamité was served to all in attendance.

\section{Presentation of a nom de guerre}

The presentation of a name or nom de guerre to British officers was connected to this larger ceremony. While the distinction between the two ceremonies is unclear from Wendat and British sources of the period, from descriptions of these events by Wendat elders in 1911, it appears that the Council of Chiefs elected the honorary chief, whereas for the presentation of a name, the Chiefs chose a name but did not hold an election. ${ }^{8}$ Madame Gros Louis explained in 1911 that "On the occasion of a sagamité feast, names were also given to strangers who would, in return, make gifts." ${ }^{\prime \prime}$ It may have been that the election and adoption of a chief recognized the

8. Marius Barbeau fonds, Fêtes Lorette, Antoine Bastien, Box 51, B.G. 13.1.

9. Marius Barbeau fonds, Mme. Gros Louis, Box 67, B-G-206.13 (1). Mme. Gros Louis was the mother of Caroline Vincent Gros Louis, artist of the moose hair-embroidered ceremonial clothing worn by Swedish Consul General Folke Cronholm. 
service to the Wendat community by the person so honoured, while the presentation of a nom de guerre recognized the recipient as a fellow warrior, particularly in times of conflict, with the possibility that the Wendat and British might in the near future be fighting side by side.

On 29 January 1840, several other officers of the Coldstream Guards were presented with a nom de guerre. These events were described in the journal of Chief François-Xavier Picard Tahourenché. It was the practice to hold two ceremonies on the same day, and Laurent Picard and FrançoisXavier Picard were made War Chiefs, before the nation and "un grand nombre d'étrangers (a large number of foreigners)." Their medals were presented by Colonel Napier, the Secretary of Indian Affairs- who himself had received a Wendat name at an earlier celebration, Sakoienteris, "he who knows us."(Sawaya, 2000a: 2178) Following the presentation of the War Chiefs, Captain Daniell of the Guards was given a nom de guerre by the Chiefs: Oienlouton, meaning many piquets of warriors. On 25 February 1840 Captain Wilbraham of the Guards also received a name: Salochiai. This was "en presence des chefs, guerriers, et des Femmes de la nation, et aussi plusieurs officiers de son régiment comme le Colonel Shaw, sa dame, Colonel Covington, sa dame, Captain Vansittart, Captain Daniel, Lord Paulett... ainsi que beaucoup de dames" (in the presence of the chiefs, warriors, and the women of the nation, and also several officers of his regiment, such as Colonel Shaw and his wife, Colonel Covington and his wife, Captain Vansittart, Captain Daniel, Lord Paulett... as well as many women) (Tahourenché, s.d.).

It is possible that James du Pre, Viscount Alexander, third Earl of Caledon and an officer in the Coldstream Guards, also received a nom de guerre. He visited Lorette frequently and his letters offer insight into his engagement with the Wendat community. He was an avid collector of Wendat moose hair-embroidered clothing and commissioned a number of works during his stay in Quebec. This collection is described in detail by Judy Hall in "The Earls of Caledon." It includes a Wendat hide coat painted with fine patterns, and the name "Annarrhideé-Huron de Lorrette" written in the back of the neck (Hall 2012: 68). Although Alexander did not mention receiving a Wendat name in his extensive letters, given that he commissioned a moose hair-embroidered waistcoat, gloves, gauntlets, and numerous pairs of moccasins, it seems likely that he also commissioned this coat, and it is possible that the name written in it is his nom de guerre. ${ }^{10}$

10. Hall 2012: 67-68; Alexander D2433/D/5/201 
To give us a perspective of these events from within the Wendat community, Widow Prudent Deschênes attended these name-giving ceremonies and her recollections were recorded by Marius Barbeau in 1911:

"Je suis allée souvent au festin sagamité. Des officiers anglais venaient
se faire donner des noms sauvages. Dans ces fêtes-là c'était le grand chef
qui distribuait la sagamité, à chacun qui avait des plats. Et chacun s'en
allait manger chez eux. Et après cela ils revenaient pour les danses " (I
often went to the sagamité celebrations. English officers came to be given
Indigenous names. In those celebrations the Grand Chief distributed
the sagamite, to everyone who had a plate. Everyone went to eat at
their own house and after that we came back together for the dance). ${ }^{11}$

\section{Celebration of the birth of a Prince}

Sir James MacDonnell's reception of Grand Chief Nicolas Vincent Tsawenhohi, the war chiefs, and members of the community was an important occasion that demonstrated the effectiveness of Wendat diplomatic traditions. The meeting with the Queen's representative was facilitated by Judge Symes Chief Hotsawati, while among the officers attending Sir James were at least three who had received a nom de guerre and one who was a Wendat chief. The Quebec populace who waited for two hours to watch the procession of over 70 Wendat from their quarters at Payne's Hotel to Chateau St. Louis were clearly familiar with and eager to see the brilliant costumes and traditions of the Wendat nation, possibly some having attended various events at Lorette in the past.

The reception was to honour Queen Victoria and the birth of her son, the Prince of Wales. Sir James was attended by his staff, a large number of Officers of the Grenadier and Coldstream Guards in dress uniform, and "a brilliant assemblage of ladies". At the Chateau, Chief Hotsawati formally introduced the Chiefs to the Lieutenant General, who "received each of them with much cordiality." Chief Nicolas Vincent Tsawenhohi made a speech to Sir James in Wendat, translated into French by war chief Michel Sioui Teacheandale. In this speech he recognized Sir James as a brave and great warrior, reaffirmed the Wendat alliance with the Crown, their continued attachment to the Queen, and their "readiness to assist in fighting her enemies". The newspaper account writes that Sir James "appeared really pleased at the opportunity this afforded him of a personal interview with the Chiefs of one of the tribes of North American Indians"(The Sydney Morning Herald, 1842).

11. Marius Barbeau fonds, Veuve Prudent Deschênes, Box 51, B-G-13.3. 
After the presentation ceremony, the Wendat delegation led the way, with a "vast concourse of people," to their own celebration of the birth of the Prince at the nearby Payne's Hotel, accompanied by the Lieutenant General and a "brilliant party" from the Chateau St. Louis event. There, following Wendat customs, a feast was held followed by traditional songs and dances (The Sydney Morning Herald, 1842). While Chief FrançoisXavier Picard Tahourenché says little about this occasion in his journal, Alexander, the Third Earl of Caledon, tells of the festivities at Payne's Hotel in a letter to his mother. He describes Sir James' surprise when he realized that "the whole village" had accepted his invitation to the reception. Alexander mentions the performance of the war dance and how the Wendat speakers made "all sorts of pretty compliments to their great mother to thank her for the illustrious baby which she has presented to her subjects." Sir James made a speech to conclude the evening; he referred to the Wendat as "Children of the Woods" and spoke of "crossing the great Salt Lake," which in Alexander's opinion "he must have got up out of one of Cooper's novels." 12 Alexander's familiarity with the novels of James Fennimore Cooper gives us interesting insights into British understandings of ceremonial adoption, which we will explore later.

The Wendat community and leaders worked strategically to maintain its presence, voice, and status as nation, among and sometimes against the competing interests of settler communities of the Quebec region. However, the ceremonies we have seen demonstrate the willing and eager engagement and participation of members of settler communities with Wendat traditions. This could be at several degrees of closeness: from becoming an honorary chief, to taking a Wendat nom de guerre, to attending such ceremonies, which as we have heard from the participants, welcomed active participation from attendees, of all ages and ranks, in dancing, visiting through open houses, sharing food together - it was a welcome into the Wendat community - and its way of life. Through analysis of these moments of engagement and specific modes of ceremonial or informal communication, on the basis of individuals or government representation, we can gain insight into the closeness and gaps in what was intended and how this was received, from the two sides of this engagement.

\section{Of Chiefs and Kings}

Elements of British tradition and knowledge of their protocols are evident in Wendat practices and their participation in European ceremony, 12. Alexander 1840 D2433/B8/41. 
for example the chief's coat, similar to officers' greatcoats, and the Chiefs' familiarity with ceremony related to the British Crown, such as the birth of the Crown Prince. An important event in Wendat history gives insight into Wendat familiarity with British protocols. In 1824, Grand Chief Nicolas Vincent Tsawenhohi, Chief Michel Tsioui Teacheandale, Chief Stanislas Coska Aharathala, and Chief Andre Romain Tsohahissan followed the Wendat tradition of visiting leaders of foreign nations to discuss issues of importance. They travelled to England to meet with George IV. The four chiefs were formally received by the King at Windsor Castle in 1825. When presented to the King, Grand Chief Nicolas Vincent Tsawenhohi broke with British protocol; he had been directed to only answer the questions asked by the King. However, he followed Great Lakes traditions of meetings between leaders, in which both chiefs speak and listen to each other, and made a speech to the King that affirmed the role of the members of the Wendat-British alliance. The portrait by Edward Chatfield captures this moment (Fig. 6). Grand Chief Nicolas Vincent Tsawenhohi and King George then conversed in French for fifteen minutes-a signal honour (Sawaya 2000a: 2130). The four chiefs spent over four months in London, and became familiar with British customs and way of life.

Wendat leaders were chosen for their abilities in public speaking, their skill of oratory and persuasion, and their moral influence and authority, values which continued at least to the end of the eighteenth century. These qualities were evident in the abilities of Grand Chief Nicolas Vincent and the three Chiefs (Lainey and Peace 2013: 207-208). The four leaders followed Wendat traditions and were confident in their position and status as chiefs of their nation, evidenced by Grand Chief Nicolas Tsawenhohi stepping away from the guidance of his British advisors and speaking directly to the King. During their visit, they were presented with four coats, in the style of military officers' dress. Seen in the portrait of the Chiefs, painted while they were in London, the epaulettes appear to reflect British uniform style (Figure 2). However, when the Chiefs returned to Wendake, Wendat women artists adapted the coats to Wendat traditions, adding moose hairembroidered epaulettes, collars, and sometimes pocket flaps (Sioui 2007). The coats were worn with silver armbands and the traditional Wendat woven sash. It is uncertain if moose hair-embroidered military great coats were part of Wendat ceremonial clothing before 1825; however, we see the coats worn by Wendat leaders as chiefly dress from this point.

As we consider these diplomatic events, we can see how Wendat traditions, through gifts received from earlier meetings with the British, 
through experiences engaging with British protocols in Canada and in England, had introduced elements that made Wendat ceremony more familiar to their British allies. In a similar way, the ceremonial events we have seen brought Wendat practices to British culture, in the Wendat space of Wendake, the British and Euro Canadian space of the city of Quebecand even the King's castle of Windsor. In Lorette, the Wendat traditional welcome of visiting Indigenous leaders was through streets decorated with boughs of pine, greeted by the entire community in their special occasion dress. This same tradition was seen in the public procession to the residence of the Lieutenant General at the Chateau Saint Louis in $1842 .{ }^{13}$ The presence of over seventy members of the Wendat nation to visit a foreign leader, brought Wendat traditions of respect and communication between nations to the etiquette and protocols of British hierarchy.

Where Wendat and British protocols differed was in the relations between leadership and community. Whereas British ceremony was based on reifying hierarchy and power, Wendat leadership was grounded in direct responsibility to their community. Community members participated in ceremonial events in a direct, egalitarian structure. For example, in spite of Grand Chief Nicolas Vincent Tsawenhohi's important role in the history of the Wendat nation, he was buried in Wendake with no special tombstone, like all other members of the community. The chiefs did not have control over community members in the way that the British monarchy had control over British subjects. The Wendat were always strategic in their engagement with foreign nations, whether Indigenous or European, and it appears that while they drew from the experience of their extended visit to the centre of Empire, their diplomacy remained grounded in Wendat culture and Indigeneity.

\section{British participation in Wendat ceremony}

Judge Symes' election as an honorary chief followed Wendat traditions of adoption to form alliance through fictive kinship networks, and at the same time, British and Euro Canadian participants brought to it their own understandings of diplomacy and ties between nations. Judge Symes' adoption ceremony followed Wendat tradition: the gifts of chiefly dress; the ceremonial words in the Wendat language spoken by the Grand Chief; the cauldron of sagamité soup that was at the centre of the ceremony, the importance of traditional songs and dances. The adoption tradition was adapted to contemporary circumstances: the birch bark scroll we see in

13. Marius Barbeau fonds, Antoine Bastien Box 51, B.G.13.1 (5). 
Chief Hotsawati's hand in the tableau portrait is probably the commission document that was read during the ceremony. The bark document was inscribed with the text of the oratory; in this gift Indigenous modes of transmission of knowledge through the oral tradition came together with Western practice of writing for public memory. This ceremony served the community in changing times, with a constant purpose: to forge new alliances and build good relations with neighbouring nations.

To British communities, the putting on of ceremonial garments and the bestowal of a new name and title had many parallels within their traditions of hierarchy, from the conferral of nobility to the investiture of a king. This would have resonated in both the honorary adoption and the presentation of a nom de guerre. The putting on of special clothing, clothing that symbolized a new state or status, was of central significance in Judge Symes' adoption ceremony. Ann Jones and Peter Stallybrass write that "it was investiture, the putting on of clothes, that quite literally constituted a person as a monarch or a freeman of a guild or a household servant." (Jones and Stallybrass 2000: 2) As the Literary Transcript reporter so tellingly noted, in his full costume Judge Roberts was "looking very like an Indian certainly." (The Literary Transcript and General Intelligencer 1838) This speaks to the materiality of clothes, that they are in some ways animate, they "pick up subjects, to mold and shape them both physically and socially, to constitute subjects through their power as material memories." (Jones and Stallybrass 2000: 2) The animate quality of the Wendat chief's dress had the power to transform, to make a Wendat chief, and take on chiefly responsibilities, represent his new community, and act in its best interests. The distinct nature of the chief's dress, as we see in the tableau portrait by Thielcke, contributed to this quality. Moose hair embroidery on lapels, leggings, and moccasins, created by Wendat artists through skills unique to the community and its family ateliers, wild turkey feathers in the headdress, silver arm bands or brassards, and the bark scroll with the text of the Grand Chief's ceremonial oratory, were marks of the singular honour bestowed on him. This is an understanding of adoption and the gifts of clothing that were part of it as a transformative process, a serious undertaking, a responsibility and life-long commitment.

The two ceremonies, the adoption as an honorary chief and the presentation of a nom de guerre, seem to reflect different levels of connection to the Wendat community; however, both generated alliances, in different spheres. Quebec or European dignitaries or community members who were welcomed as an honorary chief, from those who are known in 
the literature, had long-term connections with Wendat leadership, had assisted the community in specific ways, and after the adoption, continued to work with the Wendat in furthering relations between the Wendat and colonial institutions. Judge Symes, Chief Hotsawati, a lawyer and the first Chief of Police appointed in Lower Canada, had assisted the Wendat during the cholera epidemics of 1834, and after he became an honorary chief he facilitated introductions between Wendat leaders and British heads of state and continued to work with Wendat leaders in legal matters related to land issues (Tahourenché, s.d.). He fulfilled the commitment he had made to the Wendat during his adoption ceremony: "if at any further time I can assist you, the opportunity shall never be lost." (The Literary Transcript and General Intelligencer 1838)

The presentation of a nom de guerre appears to have been an adaptation of the Wendat community's own name-giving tradition, expanded to include young British officers. In 1911, Wendat elders Veuve Prudent Deschênes and Gaspard Picard recalled the sagamité celebrations and general tribal council meetings, attended by the community, to decide a name for a young person of the nation. The Grand Chief consulted with the other Chiefs, the names chosen or composed from the seventeenth-century Wendat dictionary written by Jesuit priest Father Chaumonot, a missionary among the Wendat at Wendake. ${ }^{14}$ The young British officers, themselves between the ages of 19 to 25, were from a Wendat perspective in the same life stage as young Wendat men who received a name. By presenting a Wendat nom de guerre to the British officers, the Wendat were in a way welcoming them into the community as adults, as Wendat guerriers. The ceremony formed relations between the communities, of respect and recognition of shared skills and interests, and was an effective way of extending the diplomatic and political influence of the Wendat community.

In a close parallel to the role of Wendat chiefs awarding noms de guerre to junior British officers, Colonel Napier, Secretary of Indian Affairs, presented medals to Laurent Picard and François-Xavier Picard when they were appointed war chiefs by the Wendat council (Tahourenché, Journal, 29 January 1840). This followed the protocols established within the federation of the Seven Nations of the Saint Lawrence Valley, by which the chiefs of one of the other nations in the federation would be present to ratify the investiture of a new chief. These events, in which British military personnel took part in Wendat ceremonies, demonstrate how

14. Marius Barbeau fonds, Veuve Prudent Deschênes, Box 51, B.G.13 (3-4); Antoine Bastien, Box 51, B.G.13.8 (14-15); Lainey (2004: 140). 
Wendat leadership adapted their traditions to the circumstances of British presence, and maintained relations between the communities in the same way that these protocols facilitated relations between Indigenous nations.

The presentation of Wendat chiefs and community members to Sir James MacDonnell, an occasion to honour the birth of the Prince of Wales, tells us much about the accommodations that facilitated relations between British military and Wendat leadership. Sir James rose to the occasion, when he received not the four chiefs he had anticipated, but the chiefs with over sixty community members. He received them with great honour, provided a feast, and participated in a traditional Wendat celebration, with performance of Wendat songs and dances. In his speech to Sir James at the Chateau ceremony, Grand Chief Nicolas Vincent Tsawenhohi recognized him as a great warrior. These words were more than mere hyperbole. Sir James' brilliant military career- he was honoured by General Wellington as the bravest man in the British army for his valour in the Battle of Waterloo- was evidently known to the Grand Chief, reflecting Wendat knowledge of the British community, ability to engage with its leadership, and respect for a courageous soldier.

For the perspective of British colonial leaders, participation of officers on the ground in the ceremonies we have explored was as strategic as it was for Wendat chiefs. It reflected British purpose: to engage with communities, avoid unrest, and maintain the cordial relations with Indigenous nations as military allies that were essential to success in the region. In 1836, Lord Glenelg, a Scottish politician and Secretary of State for War and the Colonies, referring to the wars of 1777 and 1812, wrote to Lord Gosford, then Governor General of British North America, that "there is ample Evidence that on every Occasion when this Country has been engaged in War on the North American Continent the Co-operation of the Indian Tribes has been anxiously sought and has been obtained." (Great Britain, Colonial Office, 1839: 1) In further support of the respectful relations that were to be maintained, later correspondence between Glenelg and Gosford specifies that the responsibility of the Secretary of Indian Affair, then Lieutenant Colonel Napier, was to "attend to the Representations of the Chiefs; to remedy their Grievances as far as may be practicable; to protect them in the Enjoyment of their Lands and Possessions." (Great Britain, Colonial Office, 1839: 23) In his visits to Wendake and participation in events there, Colonel Napier, Sakoienteris, "he who knows us," was a diplomat representing his nation.

The diplomatic ceremonies that facilitated the access of young British 
officers to Wendat chiefs might also have had specific military objectives. Viscount Alexander's correspondence with his mother suggests this. On 10 November 1838, at a critical point in the military engagements between British and Patriots in the region, he wrote to his mother, "I had three old chiefs over here the other day as our commandant wished to get information of the country about their place." In a letter shortly after that, he wrote that Indians were sent up and down river to verify reports of rebel meetings, saying they were on a hunting expedition. Given Alexander's frequent expeditions with Wendat hunters, his fishing trips with Wendat Chief Zachary Vincent Telariolin, and the frequent visits from Wendat chiefs at his quarters, it seems probable that it was Wendat chiefs he was meeting with, the same men he spoke with on his visits to Wendake, and Wendat hunters who were carrying out reconnaissance work for the British military, possibly the men with whom he later went on hunting expeditions. ${ }^{15}$ On one of Alexander's earliest visits to Wendake, he met with Chief Michel Tsioui Teacheandale, who told him there were two hundred fighting men in the Wendat community. This sounds very much like an assessment by Alexander of Wendat military strength. ${ }^{16}$ Two hundred fighting men, with expert knowledge of the land and shooting ability, accustomed to living on the land, would have been a strong, reassuring force if the Patriots came close to Quebec. Wendat guerriers had always honoured their commitment to fight on the side of the British. During the War of 1812, Colonel Louis de Salaberry, an officer in the Department of Indian Affairs who had himself been adopted as a warrior and presented with the name Shakoyenteresse, the connoisseur, praised and honoured the unparalleled skills of Wendat warriors (Sawaya 2015: 23, 19, 21). Hence from the perspective of British leadership on the ground at a tense time in Lower Canada, reaffirming allegiance with the Wendat would have been a critical, strategic responsibility.

\section{The souvenir, investiture, and brotherhood}

Our understanding of meanings of Wendat diplomatic ceremony to British participants, beyond governmental policies of alliance, takes us to individual soldiers and their community. These meanings and connections were formed through the specific positionality of these officers: first, a particular military understanding of souvenir and second, their familiarity with fraternal networks that crossed national and all other boundaries.

15. Alexander D2433/B/8/6; D2433/B/8/9.

16. Alexander D2433/D5/204. 
A nom de guerre and honorary adoption, together with items of moose hair-embroidered chiefly dress: these were intangible and tangible souvenirs. These experiences and objects returned to Britain with the officers who received them, where they became part of family narratives and oral tradition, mementos of a time in the Canadas. This could be interpreted as a kind of tourism, associated with romanticized notions of the noble Indian popular in the literature of the time, in particular the best-selling book by Fennimore Cooper, Last of the Mohicans. This dramatic novel, popular reading among British officers and their families of this period, involved a Mohican family adopting an American. ${ }^{17}$

It seems likely that this romanticized perspective of Wendat diplomatic ceremonies was present, but given the particular circumstances of this period, the reception of these events by British participants was more complex, more nuanced. For a soldier, the adoption ceremony and nom de guerre may also have been a form of empowerment, "an emblem of his ability to master the experience of a radically foreign environment." (Tobin 1999: 86-87) To soldiers on active service a nom de guerre or a moose hairembroidered coat were mementos of a people and place, understood from a perspective specific to the military. Susan Stewart writes that "the exotic souvenir is a sign of survival - not its own survival, but the survival of the possessor outside his or her own context of familiarity." (Stewart 1983: 148) Viscount Alexander's letters to his mother support this understanding of the souvenir as a sign of survival, specific to a combat-oriented context.

Alexander is clear that while he enjoyed the life in Quebec, this was a question of surviving in a foreign environment and in a war zone. He writes that the thermometer is at -26 and adopts local dress: "Under my coat I wear always a seal skin waist coat lined with skin of the caribou or reindeer." 18 Of combat, on 10 November 1838 he writes that "The Indians of Caughnawaga of the Iroquois tribe are engaged; they have taken 65 prisoners and the volunteers have killed 50 in an engagement," and of the likelihood of all-out war, "I do not think we can hold this country for ... longer, except we have a war with America." 19 Viewed in this context, a British military officer's perspective of Wendat diplomatic events, noms de guerre, and moose hair-embroidered clothing is less likely to be a souvenir in the sense of tourism, but at a more significant level, of personal survival and of appreciation of their Indigenous allies. It is also important

17. Alexander D2433/B/8/41.

18. Alexander D2433/B/8/19; D2433/D/5/201.

19. Alexander D2433/B/8/16; D2433/B/8/19. 
to note, in this context of ceremonial adoption and what it meant to the British officers who received these honours, that as James Axtell wrote, Indigenous peoples "despite all odds, succeeded in seducing French and English colonists in numbers so alarming to European sensibilities that the natives were conceded to be in effect the best cultural missionaries and educators on the continent." (Atxell 1985: 302) With the success of real adoptions, it is likely, in this combat context, that the honorary adoptions, noms de guerre, and Wendat clothing were highly meaningful intangible and tangible mementos.

The recollections of Ensign Sebastian Leith-Hay support this. Stationed in Quebec from 1838 to 1848 with the 93 ${ }^{\text {rd }}$ Sutherland Highlanders, his regiment was in action during the Rebellion. His letters to his mother record his strong admiration of the members of Indigenous communities he spent time with. He was made an honorary Chief by the Cree, recorded in his family history as "an honour granted to few Europeans." He went on moose hunting expeditions with a guide, Baptiste, who was probably Wendat, of whom he had the highest opinion, and acquired a moose hair-embroidered Wendat coat (Leith-Hay and Lochhead 1957: 106). The clothing acquired by soldiers of this era, such as the moose hair-embroidered coats collected by Ensign Leith-Hay and Captain Tollemache, and the painted coat of Captain Alexander, may have been a way to extend their military network, to secure their daily lives as soldiers in a potentially hostile environment (Figures 4, 5, 6) (Burgoyne 1883: 387). The nom de guerre and clothing formed their narrative of having lived and survived outside their own context of familiarity in a time of war, and their connections, on an individual level as soldiers, with foreign allies.

Wendat diplomatic ceremonies and reception as a brother warrior would have been familiar and meaningful to British military participants in other ways. The officers in Quebec were from a closely knit British military community. Many were from families who for generations had served in the military; they were frequently connected through social class, attended the same schools, and often were Freemasons. The Freemason brotherhood extended across the empire and was established within the Canadas virtually from the first days after the takeover in 1763. An international order based on mutual help and fellowship, membership was by invitation and elaborate ceremony, and was thereafter a commitment of support. To British officers, the invitation to become part of and be accepted by the Wendat nation, with the commitment of support to the Wendat and support by the Wendat, may have paralleled this fraternity. The words of Judge Symes after his 
adoption, "if at any future time I can assist you, the opportunity shall not be lost," matches the ideals of the Freemasons. British Freemasons in the Canadas included Lord Durham, Governor General of the Canadas in 1838 , the young officers in his entourage, Viscount Alexander, and many officers in the Coldstream Guards. ${ }^{20}$

\section{The familiar exotic}

To British visitors of the 1830s and 1840s, the fashionable regiments, aristocratic governor generals, government bureaucrats, and settlers and administrators establishing themselves and their government in the newly British province of Lower Canada, Indigenous traditions were foreign and exotic. Yet, at the same time, through Wendat strategic engagement with European customs, Wendat practices held the attraction of the familiar in codes of behaviour and protocols that had shared observances, creating a strong interest and allure.

The perspective of Euro Canadian Quebecers is represented by journalists at The Quebec Mercury and The Sydney Morning Herald, who wrote the articles about Judge Syme's adoption and the celebration of the birth of the Prince of Wales. Their tone was celebratory, describing festivities, the crowds of assembled Quebecers in Wendake, the crowd that waited in anticipation of the Wendat emerging from the Payne's Hotel in Quebec City, where they were dressing for the reception. At this event, the reporter writes in terms of the romantic notion of the vanishing Indian, that "the 'race of the Red Man' appears to suffer under a severe doom"(Sydney Morning Herald, September 21, 1842). However, the vibrant, strong representation of over seventy Wendat in the procession, in their finery, must have created a lasting impression, and denied this framing of a vanishing race, no matter how strongly the press clung to the notion. The full Anglophone community, families, officers, government administrators, Euro Canadians, took part in Wendat ceremonies. They then opened their own cultural events, which were embedded in their protocols and associated with their sense of national identity, to welcome Wendat participation.

Wendat chiefs drew British leaders and community into their traditions, whether the formal protocols of adoption and name giving, or the celebrations of traditional dance and song that followed. These activities reiterated Wendat customs of community cohesiveness and

20. Lady Mary Louise Lambton, 1 September 1837; 11 September 1837; 4 November 1838; 13-18 November 1838; The Freemasons' Quarterly Review, 1849: 29. 
knowledge transmission, and the Wendat included their allies to draw them into community-family relations. In these events, the full Anglophone community, senior officers, government administrators, Euro Canadians, showed strong interest in taking part in Wendat ceremonies and opened their own cultural events, embedded in their specific group protocols, associated with what was often a sense of national identity, to welcome Wendat participation.

\section{Conclusion}

The events of these four years show the adaptive, dynamic quality of Wendat diplomatic traditions and the enthusiastic engagement of British military, administrative, and Euro Canadian communities with these Wendat customs. Wendat diplomacy has its origins in pre-contact Wendat history and Great Lakes Indigenous customs of building networks of alliance and trade through creating kinship relations, and they were as relevant in the shifting political environment of nineteenth century Quebec as they were in ancient times. Here, they took on new layers of meaning as a public assertion of Wendat identity and tradition. Through them Wendat leadership and community members strategically extended their protocols to find common ground with Anglophone communities and customs. Through their program of ceremonial events, they asserted a highprofile and popular public presence in mid-nineteenth century Quebec, to engage with British and Euro Canadian leaderships on the ground and play a central role in settler community events.

From the perspective of Judge Symes, Colonel Napier, Captain Wilbraham, Captain Daniell, Lieutenant Vivian, and Viscount Alexander, the ceremony and award of a nom de guerre was an honour and also an intangible, valued souvenir: a Wendat name. Through it, they were invested with a special status, part of their own families' oral traditions, to pass on to future generations. At the same time that these ceremonies built connections with the British stationed in Quebec, they also played a role in how the Wendat were perceived by Euro Canadians in the region. The element of performance, that the Quebec population gathered to watch the Wendat community in procession and to attend ceremonial events, was an opportunity for the Wendat to occupy public space, to create recognition and presence that went far beyond their community.

A community whose population was 200 in the 1830 s navigated the power of the British Empire through these traditions. Through them leaders 
such as Grand Chief Nicolas Vincent Tsawenhohi represented their nation before King George IV, demonstrated their savoir faire and generosity before Sir James MacDonnell, the bravest warrior in the British Army, drew the British officer class to join them, and represented their nation, their culture and their Wendat identity. 


\section{References}

Primary Sources

Alexander, James Du Pre, Third Earl of Caledon. 1838-1842. Journals and Correspondence. Ref. no. D2433. Belfast: Public Records Office of Northern Ireland.

de Champlain, Samuel. 1922-1936. The Works of Samuel de Champlain, vol. 2. Toronto: The Champlain Society.

Great Britain, Colonial Office. 1839. Copies or Extracts of Correspondence since $1^{\text {st }}$ April 1835 between the Governors of the British North American Provinces, respecting the Indians in those Provinces. London: The House of Commons.

Great Britain, Parliament, House of Commons. 1839. Accounts and Papers: Colonies: British North America, Vol. 3. London: House of Commons. LAC (Library and Archives Canada). 1747. MG1-C11A, (archives des colonies, correspondence générale, Canada), vol. 117, "Dépenses générales", 1747, folio 95-116, reel F-118.

Lambton, Lady Mary Louisa. 1938. Journal of Lady Mary Louisa Lambton. Archival ref. no. R977-17-6-E. Ottawa: Library and Archives Canada.

The Literary Transcript and General Intelligencer. 1838. "Indian Festivities and Installation of Chiefs," The Literary Transcript and General Intelligencer 1(13), 24 February.

Long, John. 1971 (1791). Voyages and Travels of an Indian Interpreter and Trader. Toronto: Coles.

Marius Barbeau fonds, Box 51, B.G. 13.1. Gatineau: Canadian Museum of History.

Sydney Morning Herald. September 21, 1842.

Tahourenche, François-Xavier Picard. s.d. Journal de François-Xavier Picard Tahourenche. Wendake, QC: Archives, Conseil de la nation huronnewendat.

\section{Secondary Sources}

Axtell, James. 1985. The Invasion Within: the Contest of Cultures. New York: Oxford University Press.

Balvay, Arnaud. 2006. L'Épée et la Plume. Québec: University of Laval Press. Burgoyne, Roderick Hamilton (ed.). 1883. Historical Records of the 93 ${ }^{\text {rd }}$ Sutherland Highlanders. London: Richard Bentley and Son.

Foster, Sir John George Ross of Bladensburg. 1896. A History of the Coldstream Guards. London: A.D. Innes and Co.

Hall, Judy. 2012. "The Earls of Caledon," American Indian Art Magazine 
37(2): 66-75.

Jones, Ann Rosalind, and Peter Stallybrass. 2000. Renaissance Clothing and the Materials of Memory. Cambridge: Cambridge University Press. Jones, Howard. 2009. A History of American Foreign Relations to 1913. Toronto: Rowman and Littlefield Publishers.

Lainey, Jonathan C. 2004. La "Monnaie des Sauvages." Sillery: Les Éditions du Septentrion.

Lainey, Jonathan and Thomas Peace. 2013. "Louis Vincent Sawantanen," in Gaston Deschênes and Denis Vaugeois (eds.), Viure la conquête, Tome 1 : 216-226. Québec: Les Éditions du Septentrion.

Leith-Hay, Henrietta and Marion Lochhead. 1957. Trustie to the End: the Story of the Leith Hall Family. Oliver and Boyd.

Sawaya, Jean-Pierre. 2015. Des braves et des guerriers. Québec: Presses de l'Université Laval.

2000a. François-Xavier Picard Tahourenché, Formulaire de DemandePersonne 2000-43. Ottawa: Commission des lieux et monuments historiques du Canada.

_.2000b. Ignace-Nicolas Vincent Tsawenhohi, Formulaire de DemandePersonne 2000-41. Ottawa: Commission des lieux et monuments historiques du Canada.

Sioui, Linda. 2007. "The Huron-Wendat Craft Industry from the Nineteenth Century to Today." Musée McCord Museum: http:// collections.musee-mccord.qc.ca/scripts/printtour.php?tourID $=\mathrm{cw}_{-}$ huronwendat_en\&Lang=2. Visited 19 August 2017.

Stewart, Susan. 1983. On Longing. Durham: Duke University Press.

Tobin, Beth Fowkes. 1999. Picturing Imperial Power: Colonial Subjects in Eighteenth-Century British Painting. Durham and London: Duke University Press.

Trigger, Bruce. 1998. The Children of Aataentsic. Montreal: McGill-Queen's University Press.

Vincent, Marguerite. 1984. La Nation Huronne. Québec: Editions du Pelican, 1984. 